\title{
AN ERYTHROCYTE-SENSITISING ANTIGEN FROM VIBRIO CHOLERAE
}

\author{
G. A. Garabedian, E. L. Barsumian and A. Malakian \\ Department of Bacteriology and Virology, School of Medicine, \\ American University of Beirut, Beirut, Lebanon
}

The ABILITy of crude suspensions of Vibrio cholerae to sensitise sheep erythrocytes has been reported (Felsenfeld, Freeman and Mooring, 1955; Barua and Sack, 1964). Soluble cell-wall suspensions and intracellular substances have likewise been utilised for indirect haemagglutination (IHA) tests with tanned RBC (Burrows and Schlub, 1958). A phenol-extracted polysaccharide fraction from vibrios has been used to sensitise RBC but with variable results (Gallut, 1960). More recently, a suspension of vibrios of Ogawa and Inaba serotypes that had been disintegrated ultrasonically has been used to detect coproantibodies and serum antibodies in immunised rabbits by means of IHA tests (Agarwal and Ganguly, 1972). This communication reports the successful use of an alkali extract (AE) from strains of $V$. cholerae, probably a polysaccharide complex, in which the active principle acts as a sensitising agent in IHA tests. The simplicity of the method of extraction makes it an attractive tool for use in future investigations of the serology of $V$. cholerae.

\section{MATERIALS AND METHODS}

Strains. The $V$. cholerae cultures, of Inaba (no. 9459), Ogawa (no. 9458), and Hikojima (no. 11,558) serotypes, and of the El-Tor biotype (no. 14,033), were obtained from the American Type Culture Collection. The Escherichia coli and Salmonella enteritidis strains were locally isolated.

\section{Preparation of the antigenic extracts}

Alkali extract $(A E)$. The organisms were grown in Roux bottles containing $130 \mathrm{ml}$ of nutrient agar, $p \mathrm{H} 8 \cdot 0-8 \cdot 2$, for $18-24 \mathrm{~h}$ at $37^{\circ} \mathrm{C}$ and then harvested and washed three times with physiological saline. After the last washing the sediment from each Roux bottle was suspended in $20 \mathrm{ml}$ of physiological saline and then digested with an equal volume of $0.5 \mathrm{~N}$ $\mathrm{NaOH}$ in a water bath at $56^{\circ} \mathrm{C}$ for $5-6 \mathrm{~h}$. It was then centrifuged at 2500 r.p.m. for $5 \mathrm{~min}$., and the $p \mathrm{H}$ of the supernate was adjusted to $7.0-7 \cdot 2$ by the addition of $1.0 \mathrm{~N} \mathrm{HCl}$. The soluble bacterial substance was then precipitated by the addition of 5 volumes of absolute alcohol and stored overnight at $4^{\circ} \mathrm{C}$. The precipitate was collected by centrifugation, washed three times with acetone, and vacuum dried. In other experiments, the collected precipitate was dissoved in a minimum volume of distilled water and dialysed against distilled water for $18-24 \mathrm{~h}$ in the cold. The dialysed material was then centrifuged at $100,000 \mathrm{~g}$ in an analytic (Model L, Spinco) ultracentrifuge for $1 \mathrm{~h}$. The supernate (100S60) and the sediment (100P60) were dialysed again and lyophilised separately.

The AE was also fractionated by column chromatography on Sephadex G-200 (Pharmacia, Sweden) and eluted with phosphate buffer $(0.01 \mathrm{M}, p \mathrm{H} \mathrm{7.2)}$. The fractions were

Received 26 June 1973; accepted 28 Jan. 1974.

J. MED. MICROBIOL.-VOL. 8 (1975) 
dialysed against distilled water in the cold for $48 \mathrm{~h}$ with frequent changes of water, and lyophilised.

Enzyme-treated extract. To study the effect of enzymes on the antigen, portions of the Inaba AE ( $2 \mathrm{mg}$ per $\mathrm{ml})$ were treated separately with trypsin $(0.2 \mathrm{mg}$ per $\mathrm{ml}, p \mathrm{H} 8.2)$ for $5 \mathrm{~h}$ at $37^{\circ} \mathrm{C}$ and with ribonuclease (RNAase) $(0.2 \mathrm{mg}$ per ml, $p \mathrm{H} \mathrm{7.4})$ for $3 \mathrm{hr}$ at $37^{\circ} \mathrm{C}$. The enzymatically-treated antigens were then dialysed against distilled water for $18 \mathrm{~h}$ in the cold and lyophilised. These antigens together with control AE were tested by IHA against homotypic and heterotypic immune sera.

\section{Preparation of antisera}

Twenty-four-hour-old cultures of $V$. cholerae on agar slants were washed twice with physiological saline and the suspension was boiled for $2 \mathrm{~h}$ in a water bath to destroy the $H$ (flagellar) antigen. The bacterial suspension from each $V$. cholerae strain was diluted with physiological saline to a density of $10^{10}$ cells per ml.

For immunisation of rabbits, a 3-week schedule was followed. A first dose of $1.5 \mathrm{ml}$ of vaccine was injected into the foot-pads and the nuchal areas of the animals. Thereafter, at weekly intervals, the animals were given 1-ml booster doses of vaccine subcutaneously in the nuchal areas. A week after the last injection, the animals showing titres of 640 or over in agglutination tests with homotypic antigen were bled to death and the sera collected, pooled and stored at $-20^{\circ} \mathrm{C}$.

Antisera against $E$. coli and $S$. enteritidis were obtained from Difco laboratories. Polyvalent cholera antiserum was obtained from the Wellcome Research Laboratories.

\section{Serological tests}

Antigen for agglutination tests was prepared by washing 24-h-old agar cultures of $V$. cholerae with physiological saline. The suspension was heated for $2 \mathrm{~h}$ in a water bath at $100^{\circ} \mathrm{C}$ and standardised to contain $10^{9 \cdot 2}$ organisms per ml. Agglutination tests were performed with serial dilutions of serum (volume $0.5 \mathrm{ml}$ ) in small tubes and equal volumes of antigen. The tubes were then placed in a water bath at $56^{\circ} \mathrm{C}$ for $2 \mathrm{~h}$, followed by incubation at $37^{\circ} \mathrm{C}$ for $18-24 \mathrm{~h}$. The readings were taken by means of an agglutinoscope.

For the IHA test, fresh human group-O blood, $20 \mathrm{ml}$, was mixed with $20 \mathrm{ml}$ of modified Alsever's solution (Bukantz, Rein and Kent, 1946). This was stored at $4^{\circ} \mathrm{C}$ and was used within 9 days. A portion of the blood was centrifuged and the $R B C$ were washed with $10 \mathrm{ml}$ of physiological saline. This was repeated three times. Sensitisation of RBC was carried out by mixing nine parts of antigen (w/v), containing $2 \mathrm{mg}$ per $\mathrm{ml}$ of bacterial extract in $1 \mathrm{ml}$

\section{TABLE I}

Titration of the Vibrio cholerae (Ogawa) AE* against polyvalent $V$. cholerae rabbit antiserum in indirect haemagglutination tests

\begin{tabular}{c|c}
\hline $\begin{array}{c}\text { Concentrations of the AE } \\
\text { used for sensitisation of } \\
\text { erythrocytes (mg per ml) }\end{array}$ & $\begin{array}{c}\text { Titres of haemagglutination } \\
\text { by } V \text {. cholerae polyvalent } \\
\text { rabbit antiserum }\end{array}$ \\
\hline & \\
6 & 640 \\
4 & 640 \\
2 & 640 \\
1 & 320 \\
0.5 & 320 \\
0.25 & 160 \\
0.125 & 10 \\
\hline
\end{tabular}

* Material extracted with alkali and precipitated with alcohol (see text). 
of physiological saline, with one part of packed RBC. The mixture was incubated in a water bath at $37^{\circ} \mathrm{C}$ for $2 \mathrm{~h}$ with occasional shaking. The $\mathrm{RBC}$ were then centrifuged and washed once with physiological saline and a $0.5 \%$ suspension prepared in the same solution.

The IHA tests were performed in round-bottomed test tubes $(100 \times 13 \mathrm{~mm})$. Serum diluted 1 in 10 in physiological saline was placed in a water bath at $58-60^{\circ} \mathrm{C}$ for $20 \mathrm{~min}$., and then used to prepare doubling dilutions of $0.25-\mathrm{ml}$ volume in physiological saline. Next, $0.25 \mathrm{ml}$ of the sensitised erythrocytes was added to each of the tubes. Control tubes of sensitised and of normal RBC, but without serum, were also prepared. The tubes were shaken and left at room temperature for $1 \mathrm{~h}$, after which readings were taken according to the pattern of settled RBC. In positive tests, the RBC formed clumps and settled in an irregular pattern at the bottom of the tube. In negative tests they settled evenly assuming a button-like appearance.

\section{RESULTS}

The concentrations of the AE from the $V$. cholerae capable of sensitising erythrocytes are shown in table I. An antigen concentration of $2 \mathrm{mg}$ per $\mathrm{ml}$ was found to be the smallest amount giving maximum titres in the test, and therefore this concentration was used in subsequent determinations.

The results of bacterial agglutination and of IHA tests are presented in table II. High titres were obtained when the $V$. cholerae serotypes (Ogawa, Inaba, Hikojima) and E. coli, and S. enteritidis were tested against their homotypic antisera. Contrariwise, low titres or titres of less than 10 were obtained when they were tested with heterotypic immune sera. The titres of the IHA tests were in a number of cases somewhat higher and more specific than those of bacterial agglutination tests. It was apparent from these results that the El-Tor biotype used in these tests belonged to the Inaba serotype.

Table III shows a comparison of the sensitivity and the specificity of the $\mathrm{AE}, 100 \mathrm{P} 60$ and $100 \mathrm{~S} 60$ antigens in IHA tests. The El-Tor vibrios, E. coli

TABLE II

Titres of Vibrio cholerae, El-Tor vibrio, Escherichia coli and Salmonella enteritidis rabbit antisera in agglutination and indirect haemagglutination tests

\begin{tabular}{|c|c|c|c|c|c|c|c|c|c|c|c|c|}
\hline \multirow{3}{*}{$\begin{array}{l}\text { Bacterial } \\
\text { strain }\end{array}$} & \multicolumn{12}{|c|}{ Titre of antiserum prepared against } \\
\hline & \multirow{2}{*}{\multicolumn{2}{|c|}{$\overbrace{\text { Aggl. }{ }^{*} \text { IHA } \dagger}^{\text {(Ogawa) }^{\text {cholerae }}}$}} & \multicolumn{2}{|c|}{$\begin{array}{l}V . \text { cholerae } \\
\text { (Inaba) }\end{array}$} & \multicolumn{2}{|c|}{$\begin{array}{l}V \text { cholerae } \\
\text { (Hikojima) }\end{array}$} & \multicolumn{2}{|c|}{$\begin{array}{l}\text { El-Tor } \\
\text { vibrio }\end{array}$} & \multicolumn{2}{|c|}{ E. coli } & \multicolumn{2}{|c|}{$\underset{\text { enteritidis }}{S .}$} \\
\hline & & & Aggl. & IHA & Aggl. & IHA & Aggl. & IHA & Aggl. & IHA & Aggl. & IHA \\
\hline $\begin{array}{l}V . \text { cholerae } \\
\text { (Ogawa) }\end{array}$ & 320 & 640 & 320 & 20 & 160 & 640 & 320 & 20 & $<10$ & $<10$ & $<10$ & $<10$ \\
\hline $\begin{array}{r}\text {. choler } \\
\text { (Inaba } \\
\text { V. choler }\end{array}$ & 40 & & 640 & 1280 & 160 & 40 & 640 & 1280 & $<10$ & $<10$ & $<10$ & $<10$ \\
\hline $\begin{array}{l}\text { (Hikojima) } \\
\text { El-Tor vibrio } \\
\text { E. coli } \\
\text { S. enteritidis }\end{array}$ & $\begin{array}{r}160 \\
80 \\
<10 \\
<10\end{array}$ & $\begin{array}{r}20 \\
40 \\
<10 \\
<10\end{array}$ & $\begin{array}{r}80 \\
640 \\
<10 \\
<10\end{array}$ & $\begin{array}{l}<10 \\
1280 \\
<10 \\
<10\end{array}$ & $\begin{array}{r}640 \\
80 \\
<10 \\
<10\end{array}$ & $\begin{array}{r}1280 \\
20 \\
<10 \\
<10\end{array}$ & $\begin{array}{r}160 \\
640 \\
<10 \\
<10\end{array}$ & $\begin{array}{l}<10 \\
1280 \\
<10 \\
<10\end{array}$ & $\begin{array}{l}<10 \\
<10 \\
640 \\
<10\end{array}$ & $\begin{array}{l}<10 \\
<10 \\
320 \\
<10\end{array}$ & $\begin{array}{l}<10 \\
<10 \\
<10 \\
320\end{array}$ & $\begin{array}{l}<10 \\
<10 \\
<10 \\
1280\end{array}$ \\
\hline
\end{tabular}

* Obtained in bacterial agglutination test.

$\dagger$ Obtained in indirect haemagglutination test with AE (see footnote to Table I)

$\ddagger$ Polyvalent $\mathrm{O}$ antisera. 
TABLE III

Titres in indirect haemagglutination (IHA) tests with various antigenic preparations of Vibrio cholerae

\begin{tabular}{|c|c|c|c|c|c|c|c|c|c|}
\hline \multirow{3}{*}{ Antiserum } & \multicolumn{9}{|c|}{ Titre of IHA by the stated antiserum of RBC sensitised with extract } \\
\hline & \multicolumn{3}{|c|}{$\mathrm{AE}^{*}$ of strain } & \multicolumn{3}{|c|}{$100 \mathrm{P} 60 \dagger$ of strain } & \multicolumn{3}{|c|}{$100 \mathrm{~S} 60 \ddagger$ of strain } \\
\hline & Ogawa & Inaba & Hikojima & Ogawa & Inaba & Hikojima & Ogawa & Inaba & Hikojima \\
\hline $\begin{array}{l}\text { Ogawa } \\
\text { Inaba } \\
\text { Hikojima } \\
\text { El-Tor } \\
\text { E. coli } \\
\text { S. enteritidis }\end{array}$ & $\begin{array}{r}640 \\
20 \\
640 \\
20 \\
<10 \\
<10\end{array}$ & $\begin{array}{r}40 \\
1280 \\
40 \\
1280 \\
<10 \\
<10\end{array}$ & $\begin{array}{r}20 \\
<10 \\
1280 \\
<10 \\
<10 \\
<10\end{array}$ & $\begin{array}{r}80 \\
<10 \\
320 \\
<10 \\
<10 \\
<10\end{array}$ & $\begin{array}{r}20 \\
640 \\
<10 \\
640 \\
<10 \\
<10\end{array}$ & $\begin{array}{r}40 \\
<10 \\
640 \\
<10 \\
<10 \\
<10\end{array}$ & $\begin{array}{r}640 \\
<10 \\
1280 \\
<10 \\
<10 \\
<10\end{array}$ & $\begin{array}{r}40 \\
2560 \\
<10 \\
2560 \\
<10 \\
<10\end{array}$ & $\begin{array}{r}40 \\
<10 \\
2560 \\
<10 \\
<10 \\
<10\end{array}$ \\
\hline
\end{tabular}

* See footnote to Table I.

$\dagger$ Pellet after centrifuging $\mathrm{AE}$ at $100,000 \mathrm{~g}$.

¥ Supernatent after centrifuging $\mathrm{AE}$ at $100,000 \mathrm{~g}$.

and $S$. enteritidis are also included in the test. The $100 \mathrm{~S} 60$ fraction gave a slightly higher titre with the homotypic antiserum than did the $\mathrm{AE}$ or the $100 \mathrm{P} 60$ antigen. Likewise the cross reactivities between various serotypes were at their minimum when the $100 \mathrm{~S} 60$ fraction was used as antigen in IHA tests. The non-reactivity of $E$. coli and $S$. enteritidis antisera with $V$. cholera extracts and the high titres of El-Tor antiserum obtained in reactions with Inaba antigens are to be noted.

Fig 1 presents the elution pattern of the crude $\mathrm{AE}$ of $V$. cholerae Inaba

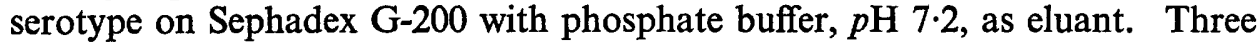
fractions were obtained. The sensitivity and specificity of the three fractions were determined in IHA tests (table IV). Fraction II gave a titre of 640 both with homotypic and the El-Tor antisera and a titre of less than 10 with other

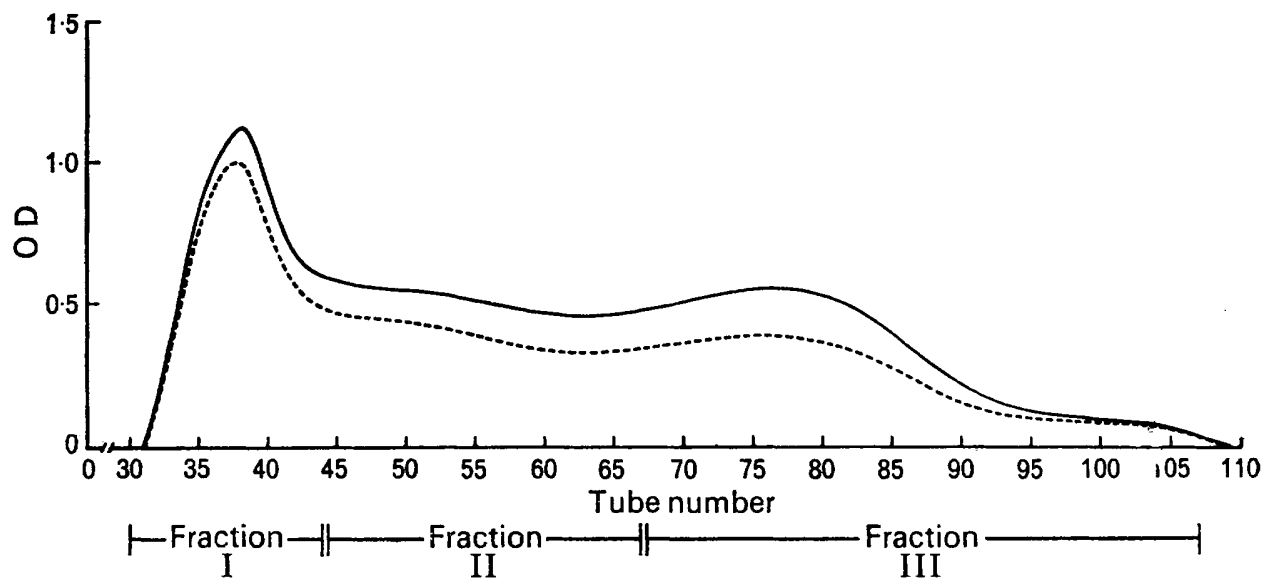

FIG. 1.-Elution profile of the AE of Vibrio cholerae (Inaba) on Sephadex G-200 at $280 \mathrm{~nm}(-)$ and $260 \mathrm{~nm}(---)$. 
TABLE IV

Titres in indirect haemagglutination (IHA) tests of Vibrio cholerae (Inaba) antigenic fractions (I, II and III) obtained by column chromatography on Sephadex G-200

\begin{tabular}{l|rrrr}
\hline \multirow{2}{*}{ Antiserum } & \multicolumn{4}{|c}{ Titre of IHA by the stated antiserum of RBC sensitised with } \\
\cline { 2 - 5 } & $\overbrace{}^{\text {AE* }}$ & Fraction I & Fraction II & Fraction III \\
\hline Ogawa & 40 & $<10$ & $<10$ & $<10$ \\
Inaba & 1280 & 40 & 640 & $<10$ \\
Hikojima & 40 & $<10$ & $<10$ & $<10$ \\
El-Tor & 1280 & 320 & 640 & $<10$ \\
\hline
\end{tabular}

* See footnote to Table I.

cholera antisera. Fraction I gave a titre of 40 with its homotypic antiserum and $1: 320$ with the El-Tor antiserum. The titres with fraction III were less than 10 with all sera tested.

A comparison of spectophotometric absorption patterns of the AE, 100P60 and 100S60 fractions of $V$. cholerae Inaba serotype, is presented in fig. 2. Absorption at $260 \mathrm{~nm}$ shows a hump that may be indicative of the presence of nucleic acid. The Inaba AE antigen treated with RNAase showed a marked decrease in its nucleic-acid content as shown in fig. 3A, without losing to any significant extent its sensitivity and specificity in IHA tests (table V). The $\mathrm{AE}, 100 \mathrm{P} 60$ and 100S60 fractions were Molisch-positive.

\section{DisCUSSION}

It is apparent from the results that $V$. cholerae extracts used in the present investigations were not free from non-specific components, yet they generally yielded somewhat more specific results in IHA tests than did bacterial suspensions in agglutination tests (table II). The extracts probably contained more than one antigen and this may explain the relative cross reactivities between the various preparations. The results of IHA tests indicate that each sensitising

TABLE V

Effect of ribonuclease and trypsin treatment on AE antigen* of Vibrio cholerae (Inaba)

\begin{tabular}{l|cccc}
\hline Antiserum & $\overbrace{\text { Untreated }}^{\begin{array}{c}\text { Titre of indirect haemagglutination by the stated antiserum } \\
\text { of RBC sensitised with AE antigen }(2 \mathrm{mg} \mathrm{per} \mathrm{ml})\end{array}} \begin{array}{c}\begin{array}{c}\text { Ribonuclease- } \\
\text { treated } \\
(0 \cdot 2 \mathrm{mg} \text { per } \mathrm{ml})\end{array} \\
\text { Untreated }\end{array}$ & $\begin{array}{c}\text { Trypsin-treated } \\
(0 \cdot 2 \mathrm{mg} \text { per ml })\end{array}$ \\
\hline Ogawa & $<10$ & $<10$ & $<10$ & 80 \\
Inaba & 640 & 320 & 640 & 180 \\
Hikojima & $<10$ & $<10$ & $<10$ & 160 \\
El-Tor & 640 & 1280 & 320 & 1280 \\
\hline
\end{tabular}

* See footnote to Table I. 


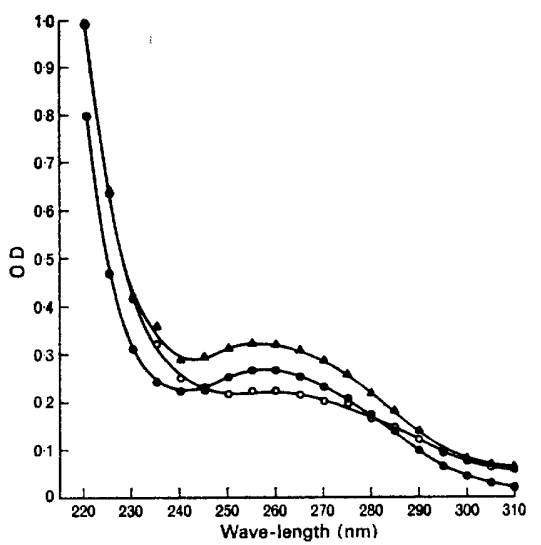

FIG. 2.-Absorption spectra of the $\mathrm{AE}(\boldsymbol{\Lambda}-\boldsymbol{\Lambda})$, and of fractions $100 \mathrm{~S} 60(-\longrightarrow)$ and 100P60 $(\mathrm{O}-\mathrm{O})$, obtained from Vibrio cholerae (Inaba).

antigen extracted from a particular serotype of $V$. cholerae contained a major antigenic component for the homotypic strain and a minor component for the heterotypic one. Nevertheless, the $V$. cholerae extracts showed no crossreactivity with $E$. coli and $S$. enteritidis extracts. The results of IHA were uniform and reproducible usually within one tube difference. Erythrocytes of both human and sheep origin could be used.

The results in table III indicate that dialysis and ultracentrifugation of the AE somewhat improved its specificity. Dialysis was used to eliminate from the extract soluble salts, breakdown products and low-molecular-weight antigenic components. The presence of such substances in the sensitising antigen might have influenced adversely the results of the IHA tests.

Of the three AE fractions obtained by Sephadex chromatography (table IV and fig. 2), fraction II gave titres closest to those obtained with the crude $\mathrm{AE}$ antigen, indicating that most of the serologically active substance was found in this fraction. The trypsinised Inaba $\mathrm{AE}$ antigen showed a significant increase in titres in IHA tests with Ogawa and Hikojima antisera (table V). This may be important, in that trypsin was probably uncoating some of the surface layers of the antigen and thus exposing the deeper antigens which apparently were less specific in their reactivity. However, when the same antigen was treated with RNAase, no significant change in IHA tests were noted despite a noticeable loss in nucleic acid content (fig. 3, A). The inability of trypsin to remove protein from the extracts, the maintenance of the titres in IHA after RNAase treatment, the ability of the extracts to sensitise untanned erythrocytes, and the positive reactions in Molisch tests of the AE, 100P60 and 100 S60 fractions, strongly suggest that the antigenic determinant in IHA tests was a carbohydrate complex.

We suggest that the $\mathrm{AE}$ is an active antigenic component of $V$. cholerae, perhaps more specific than the whole-cell antigen. It remains to be seen if this antigen could be used also for immunisation purposes. 


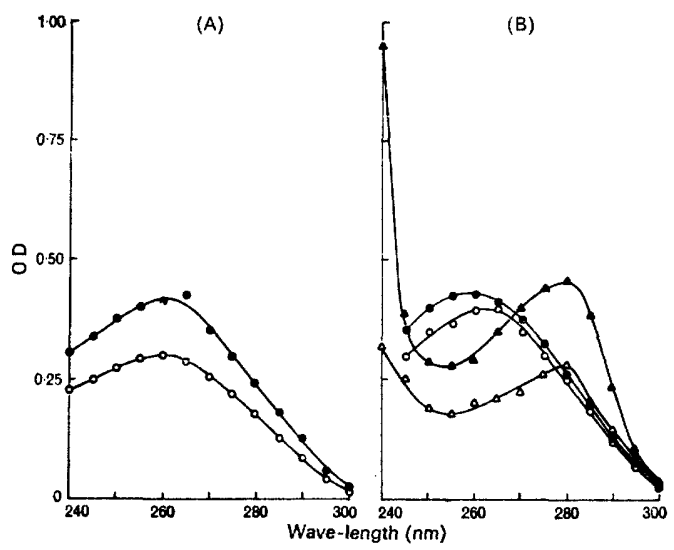

Fig. 3.-Absorption spectra of RNAase- and trypsin-treated AE of Vibrio cholerae (Inaba): A (left), $O=A E ; O \longrightarrow O=R N A a s e-t r e a t e d A E ; B$ (right), $\longrightarrow-A E, O-O=$ trypsintreated $\mathrm{AE}, \boldsymbol{\Delta}-\boldsymbol{\Delta}=$ control protein, $\triangle \longrightarrow \triangle=$ trypsin-treated control protein.

\section{SUMMARY}

Erythrocyte-sensitising antigens (AE) were prepared from Vibrio cholerae serotypes, from El-Tor vibrio, Escherichia coli and Salmonella enteritidis by digesting the organisms with $\mathrm{NaOH}$ followed by precipitation with alcohol. When AE was used in indirect haemagglutination (IHA) tests, the results in a number of cases were somewhat more sensitive and more specific than those obtained in classical agglutination tests. No cross reactions occurred between $V$. cholerae serotypes and $E$. coli and $S$. enteritidis. Much of the reactive part of the AE was not sedimentable at $100,000 \mathrm{~g}$ for $1 \mathrm{~h}$. The eluant from the $V$. cholerae AE on Sephadex G-200 yielded three fractions, one of which was the most active in IHA tests. Treatment of the AE with trypsin resulted in an appreciable increase in the heterotypic serum titres in IHA tests. The spectrophotometric absorption of the AE at $260 \mathrm{~nm}$ showed a hump that may have been indicative of the presence of nucleic acid. Treatment of the antigen with ribonuclease reduced its nucleic acid content but did not change to any significant extent the reactivity of the preparation. The AE antigen of $V$. cholerae was Molisch-positive and was capable of sensitising untanned erythrocytes in IHA tests. It is suggested that the reactive part of the AE antigen is a carbohydrate complex.

\section{REFERENCES}

Agarwal, S. C. AND Ganguly, N. K. 1972. Experimental oral immunization with L-forms of $V$. cholerae. Infect. Immun., $\mathbf{5}, 31$.

BARUA, D. AND SACK, R. B. 1964. Serological studies in cholera. Indian J. med Res., 52, 855.

Bukantz, S. C., Rein, C. R. AND Kent, J. F. 1946. Studies in complement fixation. II. Preservation of sheep's blood in citrate dextrose mixture (modified Alsever's solution) for use in the complement fixation reaction. J. Lab. clin. Med., 31, 394.

Burrows, W. AND Schlub, L. J. 1958. Studies on immunity to Asiatic cholera. X. Heat stable cell wall and intracellular antigens of $V$. cholerae independent of agglutinogens and demonstrable by passive hemagglutination. J. infect. Dis., 102, 94 . 
Felsenfeld, O., Freeman, N. L. ANd Mooring, V. L. 1955. Tube and slide technic in the hemagglutination of vibrio comma. Am. J. trop. Med. Hyg., 4, 318.

Gallut, J. 1960. Contribution à l'étude du complexe antigènique " $O$ " des vibrions. Relations immunologiques entre $V$. cholerae et vibrions dits inagglutinables (NAG). Annls Inst. Pasteur, Paris, 99, 28. 